Quote as : Ajzen, M., Taskin, L. (2021) The re-regulation of working communities in the contexte of flexwork : A spacing identity approach. Information and Organization, 31(3), https://doi.org/10.1016/j.infoandorg.2021.100364

\title{
The re-regulation of working communities and relationships in the context of flexwork: a spacing identity approach
}

\begin{abstract}
Existing studies on flexwork stress its individualizing inclination by showing how it gives autonomy to employees, boosts individual productivity, or supports personal well-being at the expense of group cohesiveness, social ties and other characteristics of the "collective" in organizations. Obviously, flexwork both continues and contributes to an individualization process of working activities and relationships. But, how exactly does flexwork re-regulate working relationships and communities? Is the "collective" irremediably damaged and doomed to disappear? Building on a case study conducted in an insurance company having implemented flexwork, we observe invisibilized employees working from diverse premises (e.g., home, office, etc.) initiating alternative ways of staying united and close. This article shows the re-regulation of these working relationships and communities' through a collective identity process involving de/re-spacing identity; i.e., the spatial and material aspects of flexible work in relation to identity.
\end{abstract}

Keywords: flexwork, collective identity, spacing identity, regulation, working communities, working relationships 
Quote as : Ajzen, M., Taskin, L. (2021) The re-regulation of working communities in the contexte of flexwork : A spacing identity approach. Information and Organization, 31(3), https://doi.org/10.1016/j.infoandorg.2021.100364

\section{Introduction}

Flexwork was developed in the 1980s as an alternative to rigid work practices and employment regulations. The term refers to specific work practices that combine flexibility in time and location such as telework, open space or shared offices (e.g., Richardson, 2010; De Menezes and Kelliher, 2011; 2017; Richardson and McKenna, 2014; Vilhemson and Thulin, 2016). Such flexibility allows employees to better reconcile their home and working lives (Kelliher and Anderson, 2012; Berkery, Morley, Tiernan, Purtill and Parry, 2017). While information and organization studies have shown mixed effects of flexwork on individual outcomes such as work-life balance, well-being, job satisfaction, productivity or commitment (Golden, Veiga and Dino, 2008; Martin and McDonnell, 2012; Peters, Poutsma, Van Der Heijden, Bakker and De Bruijn, 2014; Boell, Cecez-Kecmanovic and Campbell, 2016), more critical research in the field tends to present flexwork as part of a more profound trend that individualizes work practices and relationships (Jaakson and Kallaste, 2010; Tietze and Nadin, 2011; Huws, 2014).

This latter stream of research suggests that flexwork re-regulates working relationships and communities in the sense of weakening or dissolving them, pointing to virtualization (Vayre and Pignault, 2014), invisibility (Costas, 2013; Hirst, 2011) or de-humanization (Taskin, Parmentier and Stinglhamber, 2019). However, little has been said of this process. One characteristic of a social re-regulation process is that of being appropriated and enacted by workers rather than imposed upon them. Therefore, to study re-regulation processes in organizations, it is necessary to consider how employees experience work activities and relationships - in our case, in the context of flexwork. Re-regulation emphasizes the continuing contests and contradictions of any work system (Taskin and Edwards, 2007). We follow this approach by focusing on the tensions of flexwork and the ways in which they manifest themselves in an organization. Flexwork was not a 'solution,' but rather an organisational practice with contradictory implications for patterns of working communities and relationships. Our investigation illustrates how this re-regulation of the 'collective' is deeply rooted in identity and spatial dynamics.

This paper investigates how flexwork may affect working relationships and communities through a re-regulation of work. In particular, we focus on the role collective identity plays in this re-regulation. Extant studies address the impact of flexwork on individual outcomes such as autonomy, engagement, performance or well-being of the workers affected (McNall, 
Quote as : Ajzen, M., Taskin, L. (2021) The re-regulation of working communities in the contexte of flexwork : A spacing identity approach. Information and Organization, 31(3), https://doi.org/10.1016/j.infoandorg.2021.100364

Masuda and Nicklin, 2010; Gerards, de Grip and Baudewijns, 2017; Solis, 2017; Ongaki, 2019) and, more critically, contribute to an individualizing consideration of flexwork. The present study, while offering data on these matters, places flexwork in the context of organizational politics and investigates how collective identity re-regulates. This article highlights the conditions mediating between the technology of flexwork and a collective outcome like collective identity. We enabled this by showing the role of space in re-regulating collective identity. Building on recent work by Stang-Valand and Georg (2018), we show how the re-regulation of working relationships and communities reported here is characteristic of spacing identity work.

This paper is based on a case study conducted in a Belgian subsidiary of an American insurance company where flexwork was introduced to reduce costs and boost employee productivity. Drawing on 30 semi-structured interviews, 21 days of non-participant observation, and document analysis, we specifically highlight the mechanisms (social regulations and tools) by which dispersed workers re-create collective arenas for organizational socialization, collaborative work and friendship — which we define as reregulating working communities.

The paper is structured as follows. First, the analysis is placed in the context of the relevant literature on flexwork, work re-regulation and collective identity. The background of the case and the methodology of the study are then presented. Results are next laid out in turn. The discussion section addresses the contributions of the paper: first, flexworkers enact workspace changes and find capacities to re-appropriate spaces (both physical and virtual); second, this is a dynamic process built over time from de-spacing to re-spacing collective identities; and third, it considers collective spatial resistance in the study of spacing identity.

\section{Literature review}

\subsection{Flexwork in information and organization studies: towards individualization}

In recent years, a particular interest has been paid to the notion of flexible work. The latter has been assigned a wide range of labels including "flexwork(ing)," "flexible work" and "flexible working arrangements" that are used interchangeably to refer to a set of flexibility practices. Some authors refer to workplace flexibility (or locational flexibility; see Fogarty, Scott and Williams, 2011) - such as teleworking practices, and/or working time flexibility - such as 
Quote as : Ajzen, M., Taskin, L. (2021) The re-regulation of working communities in the contexte of flexwork : A spacing identity approach. Information and Organization, 31(3), https://doi.org/10.1016/j.infoandorg.2021.100364

flexitime and compressed working (Richardson, 2010; De Menezes and Kelliher, 2011; 2017; Richardson and McKenna, 2014; Vilhemson and Thulin, 2016). Others include non-standard work arrangements or contingent work more closely related to the employment relationship, such as employee or job sharing; casual work; crowd employment; or voucher-based work (Eurofound, 2015; Berkery et al., 2017). The difference between these approaches may lie in the distinction proposed by Alis, Karsten and Leopold (2006) between flexibility for employees and flexibility of employees; or that suggested by Berkery et al. (2017) between employee-oriented practices focused on the work-life balance and individual preferences and employer-oriented practices supporting the response to volatile market needs. Flexwork is often defined as focusing on flexibility practices for employees and refers to "(...) arrangements that allow employees to vary the amount, timing, or location of their work" (De Menezes and Kelliher, 2011:2). The flexibilization of space encompasses the flexible use of workspaces located both at home (e.g., teleworking) and in the office (e.g., flexdesk), as well as in other locations such as buses, trains, or hotels (Felstead, Jewson and Walters, 2005; Kingma, 2018). The flexible use of time refers to floating schedules and the ability to work extensively, especially since employees are permanently connected to their professional networks (Kelliher and Anderson, 2010; Hislop and Axtell, 2011; Cavazotte, Heloisa Lemos and Villadsen, 2014). Flexwork thus combines flexible space and time allowing employees to theoretically work "anywhere, anytime" and assumes an extensive use of information and communication technologies (ICT) (Brown and O'Hara, 2003; Felstead et al., 2005; Messenger and Gshwind, 2016; Bisello, Peruffo, Fernández-Macías and Rinaldi, 2019). The typical flexwork arrangement combines flexible office designs (like shared office) and homebased teleworking.

Over the last decade, research has been questioning the effects of flexwork practices on organizations, managers and employees. This body of literature shows evidence of flexwork's impact on communication, collaboration and performance. For instance, flexwork is likely to result in not only a virtualization of interactions between workers (Brown and O'Hara, 2003; Halford, 2005; Kelliher and Anderson, 2010; Vayre and Pignault, 2014) but also a potential “de-socializing” effect (Taskin and Bridoux, 2010) involving a decrease in social contacts (Hislop and Axtell, 2009; Fonner and Rolloff, 2010; Richardson, 2010; Boell et al., 2016). These studies demonstrate the contribution of flexwork practices to what McBride and Martinez Lucio (2016) called a 'work degradation,' as well as to a decrease in the social cohesiveness, support, or even trust between workers (Pyöriä, 2011; Tremblay and Thomsin, 
Quote as : Ajzen, M., Taskin, L. (2021) The re-regulation of working communities in the contexte of flexwork : A spacing identity approach. Information and Organization, 31(3), https://doi.org/10.1016/j.infoandorg.2021.100364

2012; Collins, Hislop and Cartwright, 2016). In the same vein, Hirst (2011) shows that the implementation of collaborative settings in flexwork environments did not improve collaboration but in fact reduce social interactions by avoiding serendipitous encounters at work, as affirmed by Irving, Ayoko and Ashkanazy (2019). Results from these studies show the dark side of flexwork in terms of work relationships and communities. This may explain why some organizations turned away from flexwork, as reported by Boell et al. (2016) and van der Lippe and Lippènvi (2019).

While some research highlights the positive influence of such practices on individual performance or work-life balance (McNall et al., 2010; Gerards, de Grip and Baudewijns, 2017; Solis, 2017; Ongaki, 2019), others counterbalance these results by pointing to individualization and intensification of work (Kelliher and Anderson, 2010; Felstead and Henseke, 2017). For instance, some studies demonstrate how a flexwork environment may individualize work in order to comply with a new social order oriented to managerial purposes (Alvesson and Willmott, 2002; Fleming and Spicer, 2003; Taskin, Ajzen and Donis, 2017). Kingma (2018:15) reveals how flexwork implies that workers individually select the most convenient places to perform activities efficiently. However, such individualization may also result in a feeling of isolation or disconnection from the team or the organization (see Golden et al., 2008; Hirst, 2011; van der Lippe and Lippènvi, 2019). This can even lead to feeling de-humanized due to the trifecta of dispossession, abandon and injunction to be a “modern" worker (Taskin et al., 2019). In their study of telework, Jaakson and Kallaste (2010) show how the practice implies a reallocation of responsibilities from managers to employees, adding a heavier workload to the individualizing process they report.

\subsection{Flexwork and regulation of working relationships and communities}

The literature presented above suggests a consensus on how flexwork practices may generate individualization - through isolation, invisibilization, lack of ownership or de-humanization-revealing the "de-socialization" aspect of flexwork in organizations. This reflects the challenge flexwork represents for working relationships and communities and - more broadly - for organizations and their management. Flexwork thus regulates work in the form of individualization. This in turn provokes other regulations that transpose social relationships into different spaces and times, therefore shaking the very notion of work community. 
Quote as : Ajzen, M., Taskin, L. (2021) The re-regulation of working communities in the contexte of flexwork : A spacing identity approach. Information and Organization, 31(3), https://doi.org/10.1016/j.infoandorg.2021.100364

Amidst such regulations lies the demarcation of workspace from where social relations are mostly performed and shaped. For most employees working previously in a more traditional space configuration (like an individual office or a basic open-space), flexwork practices increase the number and the type of workspaces but can also blur the demarcation in time (Wajcman, 2015) and spaces that can be either physical (Felstead et al., 2005) or virtual (Baralou and McInnes, 2013; Hafermalz and Riemer, 2020). This raises the issue of transposing social relations features from one workspace to others. Although social relations can be moved into virtual workspaces, some studies have shown a large preference for faceto-face interactions among employees, who crave the warmth of human relations (Golden et al., 2008; Vayre and Pignault, 2014). This human need for sociability requires more than "being together"; it necessitates sharing a regular physical space (Halford, 2005) or being part of a team (Hirst, 2011). By contrast, Leonardi and colleagues (2010) argue that ICT devices can be mobilized to successfully develop social relations. However, those relations might be more selective with a few chosen co-workers (Collins et al., 2016). This might explain the evolution from relational interactions towards transactional ones (Harris, 2003; Thorne, 2005; Tietze and Nadin, 2011). These less embodied relations involve the emergence of individual strategies to ensure positive relationships with peers and managers; to stay visible and show proof of work, or to establish or maintain a level of trust (Taskin and Edwards, 2007). As a result, flexworkers "manage the optics" (Richardson and McKenna, 2014:732) by mobilizing several signalling strategies (see Sewell and Taskin, 2015). While this echoes previous findings on individualization in the context of flexwork, it also shows that social relations have to re-regulate in the context of workplace (temporal and physical) distribution. For example, Gonsalves (2020) shows how a change in office spaces implies a broader use by employees of temporal flexibility practices. The way co-workers greet each other evolved from ritual to spontaneous and less visible. Consequently, a contemporary issue raised by flexwork lies in its ability to break down the collectives in order to reconfigure both the frequency of social relations at work and the organization of professional communities, which includes collective identity contexts. However, we cannot limit our understanding of workplace regulations to this unidirectional process of individualization. While space is indubitably a cornerstone of these re-regulations, we analyse how workers are capable of altering workspace regulations in order to recreate a space that is more collective. 
Quote as : Ajzen, M., Taskin, L. (2021) The re-regulation of working communities in the contexte of flexwork : A spacing identity approach. Information and Organization, 31(3), https://doi.org/10.1016/j.infoandorg.2021.100364

\subsection{A re-regulation approach to flexwork}

We consider flexwork in a pragmatic perspective, i.e., as a flexible way to organise work. While this system offers potential benefits to workers, it also re-establishes and re-defines work relationships and communities, referred to in this paper as re-regulation. Few existing studies explicitly expose how flexwork practices contribute to re-regulating work relationships and communities. One notable exception is Taskin and Edwards' 2007 study of the introduction of telework in bureaucratic organizations that pointed to a re-regulation of control processes. The current study follows debates on other socio-technical innovationse.g., total quality management, teamwork or telework - that emphasise the role of a reregulation approach (Geary and Dobbins, 2001; Bélanger, Edwards and Wright, 2003; Edwards, Rees and Collinson, 1998). Re-regulation stresses the continuing contests and contradictions of any work system. For example, it has been showed that "even 'successful' schemes do not dissolve relations of control and subordination or secure some kind of wideranging worker empowerment" (Taskin and Edwards, 2007: 197). Studies of teamwork pursuing this approach show that innovations that genuinely increased worker autonomy also produced new sets of responsibilities and performance demands (Geary and Dobbins, 2001; Bélanger et al., 2003). We follow this approach in addressing the tensions of flexwork in terms of work relationships and communities, then highlight the ways in which these played out in a specific organizational context. Based on the above, re-regulating work relationships and communities would involve a re-regulation of the collective identity, taking roots in the spatial configuration of flexwork. In a nutshell, our research questions how flexwork reregulates the "collective" in terms of its (physical) form and identity.

We therefore consider these re-regulation processes as intertwined. Collective identities are approached as a discursive construct highlighted by narratives (Brown, 2006). This raises the specter of multiple collective identities defined through social processes involving social relations dynamics (e.g., meetings, informal talks, networking, etc.), also called "plurivocity" (Brown, 2006). The very idea of "re-regulation" refers to temporality: organizational rules and norms were set in place, then they had to change with the introduction of flexwork. To access this re-regulation process, we must draw on discourse. As suggested elsewhere, discourses and narratives reveal how organizational change may provoke an identity 
Quote as : Ajzen, M., Taskin, L. (2021) The re-regulation of working communities in the contexte of flexwork : A spacing identity approach. Information and Organization, 31(3), https://doi.org/10.1016/j.infoandorg.2021.100364

destabilization. For instance, Ybema (2010) shows how temporal talk can express collective identities. Through nostalgic and postalgic discourses, organizational members “(...) frame the identity transformation either in terms of a "good past/bad present" or a "bad present/great future" contrast (2010: 495). Both discourses point to a rupture in the collective shared history but also emphasize the existence of power issues to define "who they are." This shows the changing nature of identity (Brown, 2019) while also demonstrating how “(...) a threat to a collective identity generally motivates organizational members to shore up their precarious collective selves by restoring the continuity of a positive collective identity (...)" (Ybema, 2010: 498). Consequently, a contemporary issue raised by flexwork lies in its ability to break down the collectives, to reconfigure social relations in times and spaces - and, more particularly - to question the organization of professional communities in terms of identities (Dale and Burrell, 2010; Hirst, 2011; Collins et al., 2016).

\subsection{Spacing identity and the re-regulation of work relationships and communities}

The role played by collective identity in flexwork's re-regulation effect upon working relationships and communities has been disregarded until now. Research on flexible work arrangements shows how their implementation is regulated by the collective identity, while other studies demonstrate how flexwork practices affect the collective and organizational identity. However, we may assume this regulation process is neither a mechanistic nor a oneway directional process where the working communities suffer flexwork.

As argued by Richardson and McKenna (2014): “As flexworkers alter spatial relations between work and home, as well as the social relations within them, they are constructing a new subjectivity" (2014: 734). The construction of the (new) subjectivity can be viewed as an "identity work": « (...) there is an emergent consensus that identity refers to the meanings that individuals attach reflexively to themselves, and developed and sustained through processes of social interaction as they seek the question 'Who am I?"' (Brown, 2015:23). Thus, identity is relational as it can be negotiated with others, such as work colleagues or supervisors (Brown, 2019) - and therefore be defined through social relations dynamics. Yet, as outlined by prior research investigating the dynamic between identity and space, questioning social relations at work requires consideration of the existence of a collective identity that includes the individuals' activities (Antoine, 2018); status (Rooney, Paulsen, Callan, Brabant, Gallois and Jones, 2010); or occupation (Dale and Burrell, 2010; Baldry and Barnes, 2012). For others, identity is more organizational. For example, Alvesson and Empson (2008) define 
Quote as : Ajzen, M., Taskin, L. (2021) The re-regulation of working communities in the contexte of flexwork : A spacing identity approach. Information and Organization, 31(3), https://doi.org/10.1016/j.infoandorg.2021.100364

organizational identity as " (...) the idea that organizational members construct a common perception of their organization as having certain key characteristics, as being distinctive from other organizations in some respects, and as showing a degree of continuity over a period of time and in varying circumstances” (p. 2). Similarly, Bosch-Sijtsema, Ruohomäki and Vartiainen (2010) demonstrate the link between workplace and organizational identity by revealing how flexdesk and cleandesk policies damage collective identity (at the organizational or team level) due to a perceived decrease in informal talks, collaboration, team cohesion and team belonging. Along with spatial changes, Elsbach (2004) shows how office décor - placed by either the management or individuals - reflects identity markers that may be threatened by any changes in physical and material aspects of the workspace. As Baldry and Barnes' point out in their 2012 study on the introduction of open-plan offices for academics, this new workspace setting affects the professional identity not only as "who they are as workers" but also as "how a community of work performs". In the same vein, Thatcher and $\mathrm{Zhu}$ (2006) demonstrate how identity is a cornerstone of new struggles to align with oneself and others following the introduction of telework practices. Consequently, identity reregulation is not a passive process but rather a way through which employees are able to resist perceived threats to their workplace identities (Elsbach, 2003; Cutcher, 2009; Costas, 2013). As such they argue that such reforms should be considered as part of the process of reregulating work relationships and communities.

This is precisely what Stang-Våland and Georg (2018) examine through the notion of 'spacing identity,' which they define as the notion that “( $(.$.$) emphasizes how identity is$ constituted through organizational practices taking place within, enabled by and constitutive of particular constellations of the social, material and spatial (...) Rather than being a preexisting place or framework, spacing identity is constituted and defined through interaction, through the social, material and spatial entanglements of everyday work" (2018:195). In their study, they examine how a new Danish town hall's participative design allows workers to project themselves into a space in the context of their occupation in order to simultaneously define who they are (as a community of social workers) and how to perform work (citizenoriented mission). According to Stang-Våland and Georg, both elements express a processual and collective enactment of identity. As a result, spacing identity explicitly focuses on "identity as a collective process rather than a case of the individual” (Stang-Våland and Georg, 2018: 201). 
Quote as : Ajzen, M., Taskin, L. (2021) The re-regulation of working communities in the contexte of flexwork : A spacing identity approach. Information and Organization, 31(3), https://doi.org/10.1016/j.infoandorg.2021.100364

\section{Empirical background}

\subsection{Context}

Our case originally studied the implementation of teleworking in a Belgian subsidiary of an American Insurance company located in Brussels and employing 165 white-collar workers. In recent years, the company has been engaged in a drastic programme of worldwide costcutting involving a reduction in the workforce, a structural reorganization and a revision of the work organization (e.g., by promoting skilfulness over specialization). In this context, flexwork has been perceived as a leverage mechanism to reduce costs related to both workspaces and overtime. The project, called 'NWOW' was supervised by an external business consultant, the HR manager and the facility manager. The project started in 2013 with the transformation of workspaces. Prior to this, team members were gathered in groups of no more than 6 persons and worked in closed offices, while managers had their own personal office. Currently, the departments are organized in areas with larger open spaces where personal belongings must be removed on a daily basis. Each floor has two wings, each wing includes a suite of open spaces, and each of these spaces includes between four and six sets of workspaces. Each workspace includes between four and six individual workstations, separated by a transparent window. Consequently, the number of floors was reduced from three and half in 2012 to two in 2018. The number of workstations followed the same trend. During the period from 2012-2014, both managers and employees were involved in the change process. Some of these individuals, known as "ambassadors," were responsible for providing information on expectations, fears and tensions within the teams. In addition, all employees and managers attended several workshops where they were informed about the project progress and were given an opportunity to express their feelings about it.

Then, in 2014, telework was introduced with a maximum of one day per week away from the office. The practice was conditional on the individual abandonment of the clocking system that allowed workers to receive compensatory overtime pay. In 2017 , only $12 \%$ of the workforce was still using the traditional clocking system. Therefore, the HR manager decided to extend the abandonment of the clocking system to all employees and to expand telework to two days per week. Given that online management systems allow real-time monitoring for most teams with regard to such issues as the number of tasks achieved, agenda, emails sent, and online availability, tracking by time was soon replaced by tracking of objectives met. 
Quote as : Ajzen, M., Taskin, L. (2021) The re-regulation of working communities in the contexte of flexwork : A spacing identity approach. Information and Organization, 31(3), https://doi.org/10.1016/j.infoandorg.2021.100364

This created a new work environment in which everyone became individually responsible to achieve his/her goals through spatiotemporal flexibility practices. In addition, the new orientation to goal-achievement over presence and visibility challenges the social relations at work. A colleague who used to be spatially located at the same place every day is perhaps relocated to another floor or wing, at home whether sick or healthy, in a meeting at work or at the office - but seated elsewhere. This may not only destabilize prior working arrangements but also affect the community in terms of identity and social relations. As Stang-Våland and Georg (2018) argued, amidst this re-regulation process lies the identity dimension that is questioned and expected to comply with a new managerial order involving an individual reconsideration of social and spatial-material arrangements.

\subsection{Method}

In order to investigate how work relationships and communities re-regulate in the context of flexwork, we analysed data collected between April and November 2017. Data consisted of: observations made over 21 working days (including visits to workspaces and informal discussions with employees during breaks); document analyses (e.g., policy documents, emails, status reports, presentations, etc.) and 30 semi-structured interviews with employees, managers and union representatives. To respect the privacy of interviewees, we assigned pseudonyms for the study (see Appendix A). Interviews were conducted in French; translations are ours.

After examining the empirical material and analysing its relationship with relevant research on work and identity re-regulation, we organized data following two main second-order categories or narratives (Van Maanen, 1979; Paillé and Mucchielli, 2016). Indeed, a strong binary opposition emerged rapidly between the views of the proper use of space and work relationships and communities conveyed by flexwork and those of employees. In particular, this opposition appeared characterized by either bodily absence or presence, and by practices aiming to either clean the place or de-space collective identity. All respondents expressed strong feelings about their personal way of re-connecting to the work community; therefore, they felt it necessary to re-build work relationships to continue to feel part of a team. We interpreted this expressed need as clear opposition to flexwork principles and effectsnamely, in terms of individualization. We proceeded inductively to understand this reregulation and read through our data, paying particular attention to perceptions and practices 
Quote as : Ajzen, M., Taskin, L. (2021) The re-regulation of working communities in the contexte of flexwork : A spacing identity approach. Information and Organization, 31(3), https://doi.org/10.1016/j.infoandorg.2021.100364

related to work and collective identity re-regulation. We created two major categories, gathering all processes of work and collective identity re-regulation with the space (see Appendix B). The first category expresses the "de-spacing of collective identity". This refers to the managerial attempts to "invisibilize" bodies and collective presence from the space. Three dimensions, i.e. analytical sub-categories, are associated to this process of de-spacing : depersonalization, individualization and de-socialization. The second category entitled "respacing of collective identity" entails the actions employees took to make their working community live despite distantiation. This process is analysed though three sub-categories: rebuilding proximity, re-building communities and re-solidarization.

Based on this analysis, we extracted the observations and discussions related to the reregulation of working communities and relationships involving collective identity dimension. We chose this binary analysis in order to unite our observations on these re-regulation processes, to build a narrative through the ideas of de-spacing and re-spacing identity. The objective was to identify patterns of actions in the type of interventions involved in the reregulation of the collective/space connection. Through these two categories and their subcategories, we demonstrate how workers were disconnected from the office and their colleagues, and how an intangible relationship with space was developing - namely, through telework and the use of social networks and ICT. We further convey how workers remake their working communities and collective identity present and active at work.

\section{Results}

The results are divided into two sections following the main categories identified. These sections aim to present how the introduction of flexwork initially led to a de-spacing of collective identity through the individualization and invisibilization of work(ers) prior to a respacing of collective identity highlighted by re-regulations of social relations in times and spaces.

\subsection{De-spacing of collective identity}

A key feature raised by flexworkers was the transformation of the workplace into a more impersonal and aseptic environment. The workplace refurbishment led to the redesign of offices to feature black (desk chairs and computer screens) and white (office furniture and walls) colours; while "non-working" spaces, such as the cafeteria or the coffee corners, were 
Quote as : Ajzen, M., Taskin, L. (2021) The re-regulation of working communities in the contexte of flexwork : A spacing identity approach. Information and Organization, 31(3), https://doi.org/10.1016/j.infoandorg.2021.100364

more colourful. In addition, the number of plants was decreased from 400 to 30 for the whole building. Workstations are located in large open spaces, with most files now digitized and personal belongings removed on a daily basis. Respectively, as noted by Eddy, any sign of prior human presence has been removed:

No, we arrive in the morning, we sit down where there is an available seat. We have lockers ... yes, obviously, that brings certain constraints. The clean desk, for example - you don't leave anything on your desk before leaving. It must be clean as if no one has used the workspace. (Eddy - HR Manager)

This depersonalized design of space is perceived as illegitimate by most employees. This was reflected not only in terms of emotional distance from the project but also in verbal expressions by employees, such as claims that the project name is a "stupid name" and that "it doesn't work this way”, echoing Ybema's observations (2010).

When I started working here, the files were made of paper, everything was physical. It was a personalized desk and everyone had their little family pictures, a little flower pot or a plant. It was full of plants everywhere, actually. In addition, then, it changed. Now it is black and white everywhere. (...) it was different at the beginning, when I started here. (...) It [NWOW] was a stupid name ... if we come with our laptop and we work, it is a clean desk, except that the human being doesn't work this way. (Nina-Employee)

Implying that something has changed, the new workplace is often perceived as particularly inappropriate for activities requiring concentration. This has led to different strategies like escaping from the office through telework or a meeting room in order to find more suitable working conditions. Then, the concept of 'being together' began to compete with another principle of work efficiency in terms not only of the amount of work performed but also of working conditions.

That is why I tell my team that "if you do not want to be at the office and there is no reason to be in the office, go work at home. You can better focus there and you will be much more productive. (Toma-Manager)

Since the clocking system removal, this trend is reinforced by the new importance granted to the achievement of individual goals over presence and visibility. As Charline and Greg pointed out, it no longer matters how - and even where - they perform work as long as objectives are attained.

At the end, they organize their working day however they want. I don't care as long as they've done what they had to do. (Greg-Team Leader) 
Quote as : Ajzen, M., Taskin, L. (2021) The re-regulation of working communities in the contexte of flexwork : A spacing identity approach. Information and Organization, 31(3), https://doi.org/10.1016/j.infoandorg.2021.100364

Me, that doesn't interest me at all. I evaluate regarding the work achieved, I do not evaluate the number of hours, or if they are here [at work]. (Charline-Manager)

(...) In the past, there was a clocking system and you had to work a certain number of hours... and if you did it, that was fine. Whether you were working or sleeping, it didn't matter (laughs). Now, control is on our results at the end of the month, [objectives] have to be achieved, and if it's achieved, it's fine. It's another philosophy now. (...) But the most important thing is that things get done by the end of the month. This is my own responsibility (laughs). (Cleo - Employee).

Although management intended to regulate working relations by promoting collaboration, different strategies were employed to escape the collective space. Toma's excerpt above illustrates how this exit strategy (See Hirschman, 1970) is particularly encouraged by managers' use of discretionary spatiotemporal flexibility practices to ensure all employees achieved their objectives. Indeed, on the one hand, managers are increasingly released from the responsibility to control task performance, while on the other, they are equipped with a large number of technological devices allowing instantaneous remote control, rendering the physical presence and visibility of workers unnecessary. This is why most of the workers offer to disengage from the collective to focus on individual performance and in some way thereby contribute to the individualization of the work relation (Richardson and McKenna, 2014).

I think that a large workspace is very cheerful and promotes a joyful atmosphere. We are all there, we are a family, but this is not productive. It does not promote efficiency. And I find that working at home makes you more focused from start to finish. (VincentEmployee)

I ask if it is really compulsory. I assess the importance of the meeting. There are some meetings like the daily-huddle where it is not necessary to be present for example, you can call or simply give your feedback by email and you do not have to be there. (WoutEmployee)

Interestingly, most of the remote workers voluntarily relocated activities requiring concentration to the home, where they found themselves more productive. This is mostly explained by the emergence of an informal but collective rule aiming to avoid "disturbing" colleagues at home - a phenomenon that Richardson and McKenna (2014) name 'order skills.' Three factors contribute to this. First, as remote work is perceived as more efficient, unless a lack of contact with colleague is prejudicial for one's work it would not be appropriate to disturb them. This perspective is rather transactional: it is based on the view 
Quote as : Ajzen, M., Taskin, L. (2021) The re-regulation of working communities in the contexte of flexwork : A spacing identity approach. Information and Organization, 31(3), https://doi.org/10.1016/j.infoandorg.2021.100364

that efficiency drives social relations while hinging on the hope that others reciprocate.

Second, as homeworking involves an individual organization of private and professional tasks, contacting colleagues located at home involves a degree of encroaching on their private space with working issues. This is what Richardson and McKenna (2014) call "managing spatial relations." Third, illustrating the importance of material in affecting how work should be performed, all interviewees claim preferring face-to-face interactions for operational matters. For example, Philippe said, "It is easier to explain with tangibles." However, as noted by previous studies, while these interactions appear more instrumental and transactional (Baldry and Barnes, 2012; Thorne, 2005; Tietze and Nadin, 2011) they also feel less personalized as suggested below:

It depends on the urgency level. Let us say, the 'face-to-face' is easier: when you physically meet the person, you take a paper sheet and 'look at it', but when you're at home, it is slightly more complicated. It is harder to explain, so to speak. (Philippe-Employee)

This observation provides insights into the effects of flexwork on working relationships. In the past, visibility and presence were key components of an employee's relationship to work and peers (Taskin and Edwards, 2007). Now, presence is less expected (e.g., the building could not hold all employees), and visibility can be partially re-built virtually. This reassembling of space, work and social relations shakes the employees' routines by transforming not only their perception of themselves as workers, but also their expectations of how work should be performed, as they are less visible. As stated by interviewees Kim and Kevin, flexwork practices call into question what is a "team." Their excerpts below highlight a nostalgic interpretation of the "team" to include physical closeness. In a nutshell, physical distance inside or outside the office premises is perceived as splitting the collective.

(...) But now (...) since we are on different floors, I feel that the team ... we're not truly a team anymore. (Kim - Employee)

(...) Yes, we have team-building or things like that, but it is slightly difficult to truly build a team when you come in one day [at the office] and you find one person, and, another day, it is someone else. (Kevin - Employee)

So that's what I'm saying. There is less respect for your work. (...) No team spirit, no working together because it no longer exists. (...) That's why I'm for a third or fourth day [at home] [laughs]. Ok, I say that laughing, but I find it here... after 14 years working here, respect and appreciation for our work has really decreased. (...) That's why I'm saying, why do I have to stay here? For colleagues? (Nina-Employee) 
Quote as : Ajzen, M., Taskin, L. (2021) The re-regulation of working communities in the contexte of flexwork : A spacing identity approach. Information and Organization, 31(3), https://doi.org/10.1016/j.infoandorg.2021.100364

As Nina's words highlights, flexwork led to a feeling of detachment from the collective.

Indeed, some workers associated this change with a broader degradation and depersonalization of the work atmosphere. Being dispossessed from their workspace where working social relations once occurred, they reported feelings of abandonment and isolation in the new individualized work context that promotes results over human presence and visibility. Ybema (2010) similarly wrote about how such de-socialization can destabilize the collective identity of working relations and communities.

\subsection{Re-spacing collective identity}

While we observed how flexwork practices can lead to detachment from the collective, we also found several collective strategies aimed at forming a type of work community in the face of these changes through social and spatial-material entanglements. One of these strategies involved the relocation of social relations in time and spaces (physical and/or virtual) through particular means (e.g., professional or non-professional ICT tools or physical presence). While we observed that spaces were demarcated based on the nature of the work activity, one of these demarcations involves identifying appropriated spaces to perform working relations.

For me, all these webinars, these web calls... it is good, but it does not replace the physical presence. When you meet someone and you discuss things face-to-face, it is completely different from this impersonal stuff. However, yeah, maybe I am old school. (Eden - Manager)

As articulated by Eden, face-to-face meetings enable workers to express who they are as human beings, in contrast with impersonal interactions. They require individuals to be physically together at some point. Eden's questioning of his preference as "old school" on the one hand emphasizes its association with an identity dimension. On the other hand, his preference reflects the existence of an "old" and a "new" work situation (expressing a particular order), which he resists by performing work in what might be perceived as an outmoded way - i.e., through proximity.

Re-building the proximity is also a way to attach a collective identity to a particular space. As Nina explained, selecting the same regular seats allows individuals to recognize each other through personal spaces re-appropriated based on informal collective rules reflecting who they claim to be. These rules result from social and spatial-material arrangements emerged 
Quote as : Ajzen, M., Taskin, L. (2021) The re-regulation of working communities in the contexte of flexwork : A spacing identity approach. Information and Organization, 31(3), https://doi.org/10.1016/j.infoandorg.2021.100364

from collective re-regulations of organizing space. Only two exceptions among the interviewees claim to regularly move from "their" workstation to another when they are alone within the team workspace in order to be with others.

When we are back at the place where our team is, we always choose the same places because they are familiar to us. (Emma-Employee)

(...) On Thursday, there is nobody here [on this floor]. That's why I go sitting on the fifth floor, because they're not here [on this floor]. (Nacer-Manager)

These statements stress how the workplace can be appropriated for individuals to be together. To this end, employees are reconfiguring working interactions to become more face-to-face, synchronous and scheduled. The choice to be present at the office, therefore, is mostly driven by the desire to be a part of a social community. There, employees can discuss work issues with peers and feel a sense of support.

(...) because I like having a moment when I can say 'oh, I'm sick of it' and someone else hears it... and someone tells me 'come on, let it go,' or gives feedback, or discusses it a little bit and says 'oh yes, that's a real asshole," and it reassures you a little that someone shares your feeling. (...) then okay, now I can get back to work... But also, sometimes, I feel more useful at work than at home ... (Nafissatou - Employee)

Some workers reported that being with colleagues is motivational, as they are "all in the same boat" - a phrase meaning that the workplace is something they share and have in common.

At home I have a nice apartment, but there is no contact. I have the phone, but I mean, there would be little contact. I need to talk to people, to see animation. The fact that others work, it motivates me to work too. However, if I'm alone with my laptop, I'm less motivated. It is the same thing when I was studying. I rather preferred to study in the library where you see everyone studying, so you study. While you're at home, there is nothing, sometimes you do not want to study. When you see others doing something, you do the same thing. (Ann-Employee)

The identity dimension is manifested when workers refer to "how they used to work" (e.g., the ability to ask colleagues questions, or having others around like they did as students) and, implicitly, to "who am I as a person (at work)." As reported by the union's representative, this illustrates different actions that need to be taken to recolonize the working space not only to humanize it but also to create a social life. Brown and O'Hara (2003) use pubs and cafés as examples of personalized workspaces where workers find fellows with whom they share a common social activity (work) in a common space. Acts of resistance in workspaces 
Quote as : Ajzen, M., Taskin, L. (2021) The re-regulation of working communities in the contexte of flexwork : A spacing identity approach. Information and Organization, 31(3), https://doi.org/10.1016/j.infoandorg.2021.100364

perceived as impersonal seek to emulate that environment. Since being a part of the community is a major reason to be present at the workplace, flexworkers consider teleworking for a maximum of two days per week to be feasible in order to protect a social cohesiveness.

Therefore, I would say that one day, two days, that is reasonable ... but you still have to keep a kind of ... work brings a kind of social life. It has other advantages besides earning your wage. (Marc - Union's representative)

Some of the employees voluntarily limit themselves by reducing, rescheduling or cancelling their teleworking days. Beyond the material and spatial dimensions of flexwork, the need to stand in the collective workplace also involves broader identity-related aspects: as one respondent observed, "As human beings, we need social relations, including at work - and especially in a time of robotization." Since preserving social cohesiveness is important for rebuilding community, we observed local actions taken to maintain or rebuild the way the workers' perceptions of themselves as a collective. For instance, Tia reports how her team faced a situation perceived as threatening their local identity - and therefore the very notion of 'team' - by requiring them to be outside of the workspace two days per week. Colleagues have, therefore, autonomously decided to hold regular team meetings to ensure they remain connected.

When Kevin started to telework - he also has a [part-time job] - he was at the office only 4 days a week, and then he started being here 3 days a week. In addition, we felt a little different, as if he was a little bit outside the team - as if it became necessary to strengthen this cohesion. In addition, now, we still have this regular meeting and I think that, nevertheless, we have successfully managed to maintain the proximity between us. (Tia-Employee)

In the same vein, other cases were reported in which interactions were scheduled. For instance, within some teams, a regular day (or moment) is collectively defined for telework or presence at the workplace (referred to as the formalization of coordination times in Taskin and Edwards' 2007 study). However, more informally, workers let their colleagues know about their presence and organize the forthcoming interactions accordingly. While it reinforces the use of the "do not disturb" rule, both formal and informal schedulings appear as key components to rebuilding the community. The quotes below particularly pinpoint how the "social" brought back the workplace — in its spatial-material dimension. 
Quote as : Ajzen, M., Taskin, L. (2021) The re-regulation of working communities in the contexte of flexwork : A spacing identity approach. Information and Organization, 31(3), https://doi.org/10.1016/j.infoandorg.2021.100364

(...) There are colleagues who do not see each other for three or four days, so it is still little goodbyes and reunion rituals (laughs) (...) And this is funny because it creates a team dynamic, ... When they are on-site, they are much more eager to mingle with people because they see each other less often and therefore interact more here. (Nacer - Manager)

(...) We talk more. Here? Yes. When you're in the office and you have not seen a colleague for 15 days, yes. (Marouane-Employee)

Emma and Marouane suggest that workers compensate for the reduction in social interactions allowed by flexwork by ensuring they do not miss scheduled meetings. Interestingly, the case study also shows the spontaneous emergence of another social and spatial-material arrangement across teams to re-build the community. This informal rule requires that a team maintain a physical presence by ensuring that at least one member of each team presents physically at work every day. Despite numerous tools that the company maintains for communication, the representation of each team at work is perceived as important. As Justine reports, being physically present at the workplace is not (only) a matter of visibility or availability, but also an expression of a local identity and the manifestation of both a professional and personal ethic.

(...) This is our mentality to say, "There is nobody [at work]. It is better to be present, because we never know." (...) I don't know if this gives a good impression or not. For me, it is better; I cannot explain ... Knowing that there is nobody physically at work and that I'm at home, ... I prefer to be there [at work]. (Justine-Employee)

Finally, while we mostly discuss the re-regulation of working relations and communities within the physical spaces, this process also takes place within virtual spaces through electronic devices and ICTs. From our interviews, it appears that emails are mostly used for formal and detailed communication, while the use of company chat Lync is more dedicated to short questions and small talks. Although Lync is implemented for professional purposes, some flexworkers also use it to "keep in touch" or to "gossip" with colleagues. This shows how a professional tool is appropriated to perpetuate an existing work community. Moreover, another chat system emerged within most teams: WhatsApp. This application-mostly used in the domestic sphere - spontaneously emerged as a useful device to maintain social relations between peers.

Whereas a few WhatsApp groups are mobilized for professional purposes, most are aimed at social networking. This contributes to the (re-)constitution of a community - as the result of 
Quote as : Ajzen, M., Taskin, L. (2021) The re-regulation of working communities in the contexte of flexwork : A spacing identity approach. Information and Organization, 31(3), https://doi.org/10.1016/j.infoandorg.2021.100364

the interaction between what the material, social and spatial no longer allow. Moreover, this shows how the "do not disturb" rule described above is accommodated differently according to the nature of tasks. Indeed, while we observed above that work-related interactions with remote colleagues were minimized, the quotes below highlight the existence of other types of interactions not specifically related to work. As Evi stated, even on weekends, workers exchange interactions but do not immediately reply to clients' emails. However, they try to be reactive in order to help colleagues. While we observed how flexwork practices individualize work and split collectives, this illustrates counterbalancing strategies aiming to restore solidarities.

During the week, it's [email messages] every evening, several times. I don't answer clients, but if it's a colleague I reply, "I'll do this tomorrow or next week" (...) Within the team, we are all contactable. We are all a bit like that, to help - and so yes, we work like that. And also, we are close. For example, we created a WhatsApp group for the four of us, and sometimes we send photos with what we did on weekends: we planted flowers, we cooked this or that, but (...) again this is not required by the company. It's because we want to do it. (Evi-Employee)

There are plenty of departments that use WhatsApp. (...) In fact, we have it (...), but we use it for private purposes. (...) We have become close friends in the meantime. (Michy - Employee)

Moreover, as noted by Michy, this work community relies on particular values, such as enjoyment or friendship, that extend far beyond those valued by management. Coupled with the workers' use of particular communication tools within particular spaces, these values represent a way for workers to define who they are and how they act in a particular working context.

This result reflects the building or maintaining of a work community by re-regulating working relationships through changes to the physical and virtual spaces, like chat systems. Therefore, while we outlined above that both formal and informal scheduling are key components to keeping the community alive, workers' use of electronic devices and ICTs appear to be another.

\section{Discussion}


Quote as : Ajzen, M., Taskin, L. (2021) The re-regulation of working communities in the contexte of flexwork : A spacing identity approach. Information and Organization, 31(3), https://doi.org/10.1016/j.infoandorg.2021.100364

Our investigation of the re-regulation of working communities and relationships in the context of flexwork through a spacing identity approach contributes to flexwork studies in three respects. First, adopting a re-regulation perspective allows considering individualization and collectivization as the two faces of the same coin - that is spacing identity. Second, considering the identity and spatial dynamics at stake, this article shows that the re-regulation of working communities and relationships is a process built over time from de-spacing to respacing collective identities, both in physical and virtual spaces. Third and finally, we highlight the central role of spacing identity in turning latent interrelations among various reregulations of working relationships into a powerful political contestation of the individualized workplace. Re-spacing collective identities acts therefore like acts of resistance.

\subsection{A re-regulation perspective for considering simultaneously the collective and}

\section{individual dimensions of workspace changes}

Our research results confirm most previous findings on the effects of flexwork on social relations at work (Richardson and McKenna, 2014), such as work individualization (Kelliher and Anderson, 2010); virtualization (Vayre and Pignault, 2014); invisibility (Costas, 2013; Hirst, 2011); or de-humanization (Taskin, et al., 2019). By viewing such results through a reregulation lens (Edwards et al., 1998; Bélanger et al., 2003), we show how working relationships and communities are revitalized by re-spacing collective identity.

Rather than sit passively while working relations and communities are deleted, most workers collectively develop alternative definitions to build and maintain them. Here lies the main characteristic of a re-regulation process: managerial techniques are appropriated and enacted by workers rather than imposed to them. Therefore, while workers may appear to comply with new managerial tenets of efficiency and flexibility, they do not meet these expectations at any price. As a result, they develop gambits to maintain or (re)shape their identity. This echoes Hancock and Spicer's findings (2011) on the shaping of subjectivity within hyperindividualized contexts.

Moreover, interestingly, these alternatives are built not against a managerial logic, but upon it. As noted by Taskin and Edwards (2007), re-regulation puts more emphasis on the continuing contests and contradictions of any work system. Therefore, between managerial and collective logics reside tensions that flexworkers managed by autonomously and collectively defining the ground rules for new forms of togetherness within the de-spatialised firm. For instance, 
Quote as : Ajzen, M., Taskin, L. (2021) The re-regulation of working communities in the contexte of flexwork : A spacing identity approach. Information and Organization, 31(3), https://doi.org/10.1016/j.infoandorg.2021.100364

limiting use of telework; reinventing offices for both collaborative and social purposes; assigning a period of physical presence to members representing their teams; and use of WhatsApp can all be considered as examples of how working relations and communities can be voluntary re-regulated — with clear implications for identity (see below). In contrast with Richardson and McKenna's results (2014), we find that working relations are neither instrumental nor transactional but rather community- and solidarity-oriented. This echoes a recent study conducted by Blagoev, Costas and Kärreman (2019) that examined coworking spaces under the lens of organizationality. In investigating such spaces, they show that what employees look for is a sense of community that is materially and socially grounded. In a nutshell, by revealing how flexwork practices convey contradictory implications for patterns of working communities and relationships, our investigation stresses individualization and collectivization as two faces of the same coin while also providing insight on how this reregulation of the "collective" is deeply rooted in identity and spatial dynamics.

\subsection{De-spacing and re-spacing collective identities through material and virtual spaces}

From this perspective, it is clear that space plays an important role in comprehending how flexwork re-regulates collective identities. In line with Stang-Våland and Georg's notion of "spacing identity" (2018), our results illuminate the link between space and identity, demonstrating how they are mutually (re)shaped through the intertwined social, spatial and material dimensions. However, our investigation also shows that politics are produced when prior spatial-material arrangements are shaken by flexwork. This suggests that flexwork practices produce new collective arrangements and new work habits through which a work community defines its collective identity. As a result, we demonstrate how these reregulations contain a spatialised identity dimension. While our results support the processual and collective enactment of identity depicted by Stang-Våland and Georg (2018), the second contribution of this paper is to characterize the process from a "de-spacing of collective identity" - referring to invisibilization, depersonalization, and de-socialization--to a "respacing of collective identity", which entails re-regulations that affirm "who they (the workers, collectively) are and remain" in the context of flexwork. In the midst of such process, spacing identity is created. This shows the changing nature of identity (Brown, 2019) as well as how “ (...) a threat to a collective identity generally motivates organizational members to shore up their precarious collective selves by restoring the continuity of a positive collective identity (...)" (Ybema, 2010: 498). The making of spacing identity by definition involves a temporal dimension, as a given amount of time must be allotted to balance the 
Quote as : Ajzen, M., Taskin, L. (2021) The re-regulation of working communities in the contexte of flexwork : A spacing identity approach. Information and Organization, 31(3), https://doi.org/10.1016/j.infoandorg.2021.100364

different tensions experienced by workers in re-building proximity, restoring solidarities, and re-affirming working communities. For instance, while WhatsApp offers some opportunities to keep the community alive, the need for this device probably would not have been created if space did not first isolate people. This reveals how spacing identity overcomes physical spaces as the materiality of the re-regulations observed are also grounded into virtual onesas suggested by Dery and Hafermalz (2016) and Leonardi et al. (2010).

\subsection{Spatial resistance at the heart of re-spacing collective identity}

Workplace resistance has been considered as the fruit of individual acts of resistance.

Examples can include practices such as "escaping” or "opting out" (Jones 2012), or "downshifting” (Nelson, Rademacher and Paek, 2007) and consist of cultivating anonymity and invisibility in order to be left alone. Such resistance can also involve a series of individual objections to managerial commandments and explanations of what is good, efficient and preferable and consist in re-appropriation of space through marking (see, e.g., Taylor and Spicer 2007; Clarke 2012; Courpasson et al., 2017). Compromises on how to occupy space and live together in a flexwork environment can then be approached and assimilated as productive resistances (Courpasson, Dany and Clegg, 2012) aiming to assert the expression of an existing community. What is novel in our research is that these objections are collectively organized: they all contribute to the patient elaboration of a desired spatial order that contradicts the official one. But the novel geographies of offices combine embodiment - i.e., a material reinstalment with the invisible reaffirmation of the "collective."

To some extent, the re-regulation of the working relationships and communities we describe in this paper permit the fabric of a collective silent acknowledgment of a shared definition of a "right to the collective" - i.e., a spacing collective identity. This re-regulation instantiates the latent shared understandings of a spatial situation that enables a collective response, thereby constituting new, shared perceptions of place and of the collective. Our data suggest that reregulation as such constructs a web of cohesive perceptions of place and the collective that transform a latent conflict into active opposition. We emphasize the "(...) multiple connectivities at work in place-making" (Pierce, Martin and Murphy, 2011: 56), highlighting the central role of spacing identity in turning latent interrelations among various reregulations and initiatives of working relationships and communities into a powerful political contestation of the individualized workplace. 
Quote as : Ajzen, M., Taskin, L. (2021) The re-regulation of working communities in the contexte of flexwork : A spacing identity approach. Information and Organization, 31(3), https://doi.org/10.1016/j.infoandorg.2021.100364

\section{Conclusion}

This article investigated how flexwork affects working communities and relationships by adopting a re-regulation perspective and with the aim to contribute to research on "spacing" and, specifically, on "spacing identity" (Stang-Valand and Georg, 2018). Focusing on the collective dimension of work, our contribution is threefold. First, it appears that flexworkers enact workspace changes and find ways to re-appropriate (both physical and virtual) spaces, collectively. Second, this is led by a dynamic process of re-regulation built over time from despacing to re-spacing collective identities. Third and finally, we show the re-regulation of working communities and relationships encompasses collective spatial resistance.

Future research should place more emphasis on the collective dimension of workplace changes and the related identity issues, especially in a post-Covid context where social ties seem to be damaged by isolation due to an intensive practice of telework. In this attempt, future studies ought to explore virtual spaces as part of the materiality of collective identities in spacing identity studies. This paper demonstrates how working relations are also performed through professional (i.e., company-chat system) and non-professional platforms (e.g., WhatsApp) to re-regulate collective identities. These employees are not just flexworkers, they are also a part of a broader community involving a certain proximity (even at a distance, connected through ICTs devices) and particular solidarities (some of them define themselves as friends) that ICTs devices can help to build or maintain as a form of self-expression. A possible avenue for further research would be to investigate, using a socio-material approach, the social relations that occur through these virtual spaces to question more precisely how materiality and identity are intertwined. 
Quote as : Ajzen, M., Taskin, L. (2021) The re-regulation of working communities in the contexte of flexwork : A spacing identity approach. Information and Organization, 31(3), https://doi.org/10.1016/j.infoandorg.2021.100364

Appendix A - Respondents

\begin{tabular}{|c|c|c|c|c|}
\hline$\#$ & Dates & Interviewees & Occupation & \begin{tabular}{|l} 
Interview \\
duration
\end{tabular} \\
\hline 1 & $10 / 04 / 17$ & Eddy & HR Manager & 51'09', \\
\hline 2 & $12 / 05 / 17$ & Nacer & Manager & $80^{\prime} 01^{\prime}$, \\
\hline 3 & $16 / 05 / 17$ & Greg & Team Leader & $85^{\prime} 57^{\prime}$, \\
\hline 4 & $16 / 05 / 17$ & Jan & Manager & $57^{\prime} 27^{\prime \prime}$ \\
\hline 5 & $27 / 06 / 17$ & Emma & Employee & 69'33', \\
\hline 6 & $27 / 06 / 17$ & Tia & Employee & 64'29', \\
\hline 7 & $27 / 06 / 17$ & Nina & Employee & $78^{\prime} 33^{\prime}$ \\
\hline 8 & $27 / 06 / 17$ & Nafissatou & Employee & 64'29', \\
\hline 9 & 29/06/17 & Kim & Employee & 66'17', \\
\hline 10 & $6 / 07 / 17$ & Marouane & Employee & 86’20', \\
\hline 11 & $17 / 07 / 17$ & Axel & Employee & 79'58', \\
\hline 12 & $17 / 07 / 17$ & Vincent & Employee & $89^{\prime} 50^{\prime \prime}$ \\
\hline 13 & $19 / 07 / 17$ & Kevin & Employee & 72'34', \\
\hline 14 & 20/07/17 & Kim & Manager & $51^{\prime} 11^{\prime}$, \\
\hline 15 & $26 / 07 / 17$ & Charline & Manager & $45^{\prime} 24^{\prime}$, \\
\hline 16 & $17 / 08 / 17$ & Evi & Employee & $54^{\prime} 59^{\prime \prime}$ \\
\hline 17 & $6 / 09 / 17$ & Tessa & Employee & 73'09', \\
\hline 18 & $13 / 09 / 17$ & Thibault & Employee & 42'50'” \\
\hline 19 & $19 / 09 / 17$ & Benjamin & Employee & $66^{\prime} 18^{\prime}$, \\
\hline 20 & $19 / 09 / 17$ & Justine & Employee & $88^{\prime} 55^{\prime}$, \\
\hline 21 & 20/09/17 & Wout & Union's reprensentatives & 89'59', \\
\hline 22 & $12 / 10 / 17$ & Jolien & Employee & 68'38', \\
\hline 23 & $13 / 10 / 17$ & Marc & Union's reprensentatives & $54^{\prime} 22^{\prime}$, \\
\hline 24 & $13 / 10 / 17$ & Dries & Manager & $25^{\prime} 18^{\prime \prime}$ \\
\hline 25 & $13 / 10 / 17$ & Eden & Manager & $65^{\prime} 45^{\prime}$, \\
\hline 26 & $13 / 10 / 17$ & Ann & Team Leader & 62'38', \\
\hline 27 & $20 / 10 / 17$ & Cleo & Employee & $53^{\prime} 13^{\prime}$, \\
\hline 28 & $26 / 10 / 17$ & Jacky & Union's reprensentatives & 44'01', \\
\hline 29 & $26 / 10 / 17$ & Philippe & Employee & $70^{\prime} 54^{\prime}$, \\
\hline 30 & $7 / 11 / 17$ & Michy & Employee & $64^{\prime} 15^{\prime}$, \\
\hline
\end{tabular}


Quote as : Ajzen, M., Taskin, L. (2021) The re-regulation of working communities in the contexte of flexwork : A spacing identity approach. Information and Organization, 31(3), https://doi.org/10.1016/j.infoandorg.2021.100364

\section{Appendix B - Data structuration from categories}

\begin{tabular}{|c|c|c|c|c|}
\hline Categories & Definition & Sub-categories & Definition & Illustrative verbatims \\
\hline \multirow[t]{3}{*}{$\begin{array}{l}\text { De- } \\
\text { spacing } \\
\text { collective } \\
\text { identity }\end{array}$} & \multirow[t]{3}{*}{$\begin{array}{l}\text { Managerial } \\
\text { attempts to } \\
\text { "invisibilize" } \\
\text { bodies and } \\
\text { collective } \\
\text { presence } \\
\text { from the } \\
\text { space }\end{array}$} & Depersonalization & $\begin{array}{l}\text { Work } \\
\text { environment } \\
\text { standardization } \\
\text { through } \\
\text { dispossession of } \\
\text { workstations and } \\
\text { digitalization of } \\
\text { work processes }\end{array}$ & $\begin{array}{l}\text { (...) It must be clean, as if no one has used the workspace. (Eddy-HR } \\
\text { Manager) } \\
\text { (...) When I started working here, the files were made of paper, everything } \\
\text { was physical. It was a personalized desk and everyone had their little } \\
\text { family pictures, a little flower pot or a plant. It was full of plants } \\
\text { everywhere, actually. In addition, then, it changed. Now it is black and } \\
\text { white everywhere. (...) (Nina - Employee) }\end{array}$ \\
\hline & & Individualization & $\begin{array}{l}\text { Empowering } \\
\text { employees } \\
\text { though individual } \\
\text { performance } \\
\text { management by } \\
\text { means of their } \\
\text { spatio-temporal } \\
\text { flexibility }\end{array}$ & $\begin{array}{l}\text { Me, that doesn't interest me at all. I evaluate regarding the work achieved, } \\
\text { I do not evaluate the number of hours, or if they are here [at work]. } \\
\text { (Charline - Manager) } \\
\text { That is why I tell my team that "if you do not want to be at the office and } \\
\text { there is no reason to be in the office, go work at home. You can better } \\
\text { focus there and you will be much more productive. (Toma - Manager) } \\
\text { (...) Now, control is on our results at the end of the month, [objectives] } \\
\text { have to be achieved, and if it's achieved, it's fine. It's another philosophy } \\
\text { now. (...) But the most important thing is that things get done by the end of } \\
\text { the month. This is my own responsibility (laughs) (Cleo-Employee). }\end{array}$ \\
\hline & & De-socialization & $\begin{array}{l}\text { Detachment from } \\
\text { the collective } \\
\text { (exit strategies, } \\
\text { feeling of } \\
\text { belonging) }\end{array}$ & $\begin{array}{l}\text { Yes, we have team-building or things like that, but it is slightly difficult to } \\
\text { truly build a team when you come in one day [at the office] and you find } \\
\text { one person, and, another day, it is someone else. (Kevin-Employee) } \\
\text { (...) There is less respect for your work. (...) No team spirit, no working } \\
\text { together because it no longer exists. (...) That's why I'm for a third or } \\
\text { fourth day [at home] [laughs]. (...) why do I have to stay here? For } \\
\text { colleagues? (Nina - Employee) }\end{array}$ \\
\hline
\end{tabular}


Quote as : Ajzen, M., Taskin, L. (2021) The re-regulation of working communities in the contexte of flexwork : A spacing identity approach. Information and Organization, 31(3), https://doi.org/10.1016/j.infoandorg.2021.100364

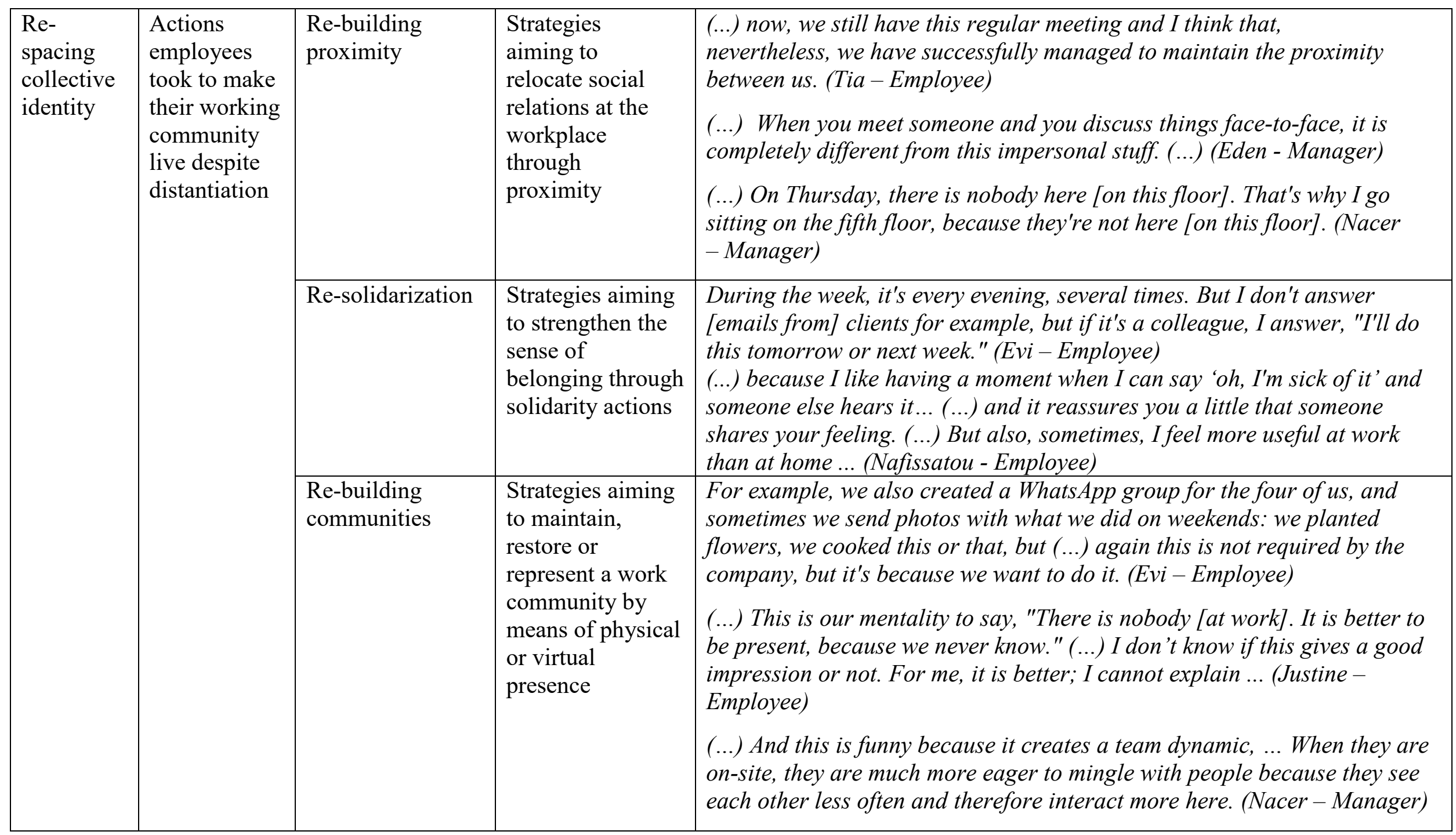


Quote as : Ajzen, M., Taskin, L. (2021) The re-regulation of working communities in the contexte of flexwork : A spacing identity approach. Information and Organization, 31(3), https://doi.org/10.1016/j.infoandorg.2021.100364

\section{References}

Alis, D., Karsten, L., \& Leopold, J. (2006). From gods to goddesses: Horai management as an approach to coordinating working hours. Times and Society, 15(1), 81-104. https://doi.org/10.1177/0961463X06062280

Alvesson, M., \& Empson, L. (2008). The construction of organizational identity: Comparative case studies of consulting firms. Scandinavian Journal of Management, 24(1), 1-16. https://doi.org/10.1016/j.scaman.2007.10.001

Alvesson, M., \& Willmott, H. (2002). Identity regulation as organizational control: producing the appropriate individual. Journal of Management Studies, 39(5), 619-644. https://doi.org/10.1111/1467-6486.00305

Antoine, M. (2018). Unveiling the organisational identity: a spatial approach based on the office. The case of ORES Picardy Wallonia transition towards an activity-based workspace. PhD dissertation. Louvain-laNeuve: Université catholique de Louvain

Ashcraft, K.L., Kuhn, T.R., \& Cooren, F. (2009). Constitutional Amendments: "Materializing" Organizational Communication. The Academy of Management Annals, 3(1), 1-64. https://doi.org/10.1080/19416520903047186

Baldry, C., \& Barnes, A. (2012). The open-plan academy: space, control and the undermining of professional identity. Work, Employment \& Society, 26(2), 228-245. https://doi.org/10.1177/0950017011432917

Baralou, E. \& McInnes, P. (2013). Emotion in virtual teams. New Technology, Work and Employment, 28(2), 160-175. https://doi.org/10.1111/ntwe.12012

Barley, S.R., Meyerson, D.E., \& Grodal, S. (2011). E-mail as a source and symbol of stress. Organization Science, 22(4), 887-906. https://doi.org/10.1287/orsc.1100.0573

Bélanger, J., Edwards, P., \& Wright, M. (2003). Commitment at work and independence from management. Work and Occupations, 30(2), 234-252. https://doi.org/10.1177/0730888403251708

Berkery, E., Morley, M. J., Tiernan, S., Purtill, H., \& Parry, E. (2017). On the Uptake of Flexible Working Arrangements and the Association with Human Resource and Organizational Performance Outcomes. European Management Review, 14(2), 165-183. https://doi.org/10.1111/emre.12103

Bisello, M., Peruffo, E., Fernández-Macías, E., \& Rinaldi, R. (2019). How computerisation is transforming jobs: Evidence from the Eurofound's European Working Conditions Survey, Seville: European Commission.

Blagoev, B., Costas, J., \& Kärreman, D. (2019). 'We are all herd animals': Community and organizationality in coworking spaces. Organization. https://doi.org/10.1177/1350508418821008

Boell, S.K., Cecez-Kecmanovic, D., \& Campbell, J. (2016). Telework Paradoxes and Practices: The Importance of the Nature of Work. New Technology, Work and Employment, 31(2), 114-131. https://doi.org/10.1111/ntwe.12063

Bosch-Sijtsema, P. M., Ruohomäki, V., \& Vartiainen, M. (2010). Multi-locational knowledge workers in the office : navigation, disturbances and effectiveness. New Technology, Work and Employment, 25(3), 183195. https://doi.org/10.1111/j.1468-005X.2010.00247.x

Brown, A.D. (2006). A Narrative Approach to Collective Identities*. Journal of Management Studies, 43(4), 731-753. https://doi.org/10.1111/j.1467-6486.2006.00609.x

Brown, A.D. (2015). Identities and Identity Work in Organizations. International Journal of Management Reviews, 17(1), 20-40. https://doi.org/10.1111/ijmr.12035

Brown, A. D. (2019). Identities in Organization Studies. Organization Studies, 40(1), 7-22. https://doi.org/10.1177/0170840618765014

Brown, B., \& O'Hara, K. (2003). Place as a Practical Concern of Mobile Workers. Environment and Planning A: Economy and Space, 35, 1565-1587. https://doi.org/10.1068/a34231

Cavazotte, F., Heloisa Lemos, A., \& Villadsen, K. (2014). Professionals in escalating work connectivity. New Technology, Work and Employment, 29: 72-87. https://doi.org/10.1111/ntwe.12022

Clarke, D. (2012). Understanding Processes of Individual Resistance to New Working Practices. In C. Kelliher \& J. Richardson (eds), New ways of organizing work, 108-121. London: Routledge.

Collins, A.M., Hislop, D., \& Cartwright, S. (2016). Social support in the workplace between teleworkers, officebased colleagues and supervisors. New Technology, Work and Employment, 31(2), 161-175. https://doi.org/10.1111/ntwe.12065

Costas, J. (2013). Problematizing Mobility: A Metaphor of Stickiness, Non-Places and the Kinetic Elite. Organizations Studies, 34(10), 1467-1485. https://doi.org/10.1177/0170840613495324

Courpasson, D., Dany, F., \& Clegg, S. (2012). Resisters at work: Generating productive resistance in the workplace. Organization Science, 23(3), 801-819. https://doi.org/10.1287/orsc.1110.0657

Courpasson, D., Dany, F., \& Delbridge, R. (2017). Politics of Place: The meaningfulness of resisting places. Human Relations, 70(2), 237-259. https://doi.org/10.1177/0018726716641748 
Quote as : Ajzen, M., Taskin, L. (2021) The re-regulation of working communities in the contexte of flexwork : A spacing identity approach. Information and Organization, 31(3), https://doi.org/10.1016/j.infoandorg.2021.100364

Cutcher, L. (2009). Resisting change from within and without the organization. Journal of Organizational Change Management, 22(3), 275-289. https://doi.org/10.1108/09534810910951069

Dale, K., \& Burrell, G. (2010). 'All together, altogether better': the ideal of 'community' in the spatial reorganization of the workplace. In A. van Marrewijk \& D. Yanow (Eds.), Organizational Spaces. Rematerializing the Workaday world (pp.17-41). Cheltenham: Edward Elgar Publishing Limited.

De Menezes, L-M., \& Kelliher, C. (2011). Flexible working and Performance: A systematic review of the evidence for a business case. International Journal of Management Reviews, 13(4), 452-474. https://doi.org/10.1111/j.1468-2370.2011.00301.x

De Menezes, L. M., \& Kelliher, C. (2017). Flexible Working, Individual Performance, and Employee Attitudes: Comparing Formal and Informal Arrangements. Human Resource Management, 56(6), 10511070. https://doi.org/10.1002/hrm.21822

Dery, K., \& Hafermalz, E. (2016). Seeing is belonging: Remote working, identity and staying connected. In Lee (eds.) The Impact of ICT on Work (pp. 109-126). Singapore: Springer.

Edwards, P., Rees, C., \& Collinson, M. (1998). The Determinants of Employee Responses to Total Quality Management : Six Case Studies, Organization Studies, 19(3), 449-475. https://doi.org/10.1177/017084069801900304

Elsbach, K. D. (2003). Relating Physical Environment to Self-Categorizations: Identity Threat and Affirmation in a Non-Territorial Office Space. Administrative Science Quarterly, 48(4), 622-654. https://doi.org/10.2307/3556639

Elsbach, K. D. (2004). Interpreting workplace identities: the role of office décor. Journal of Organizational Behavior, 25(1), 99-128. https://doi.org/10.1002/job.233

Eurofound. (2015). New forms of employment. Luxembourg: Publications Office of the European Union.

Felstead, A., Jewson, N., \& Walters, S. (2005). Changing Places of Work. Basingstoke: Palgrave MacMillan.

Felstead, A., \& Henseke, G. (2017). Assessing the Growth of Remote Working and Its Consequences for Effort, Well-being and Work-life Balance. New Technology, Work and Employment 32, 195-212. https://doi.org/10.1111/ntwe.12097

Fleming, P., \& Spicer, A. (2003), Working at a cynical distance: implications for power, subjectivity and resistance. Organization, 10(1), 157-179. https://doi.org/10.1177/1350508403010001376

Fogarty, H., Scott, P. \& Williams, S. (2011). The half-empty office: dillemas in managing locational flexibility. New Technology, Work and Employment, 26(3), 183-195. https://doi.org/10.1111/j.1468005X.2011.00268.X

Fonner, K.L., \& Roloff, M.E. (2010). Why Teleworkers are More Satisfied with their Jobs than are Office-Based Workers: When Less Contact is Beneficial. Journal of Applied Communication Research, 38(4), 336361. https://doi.org/10.1080/00909882.2010.513998

Geary, J. \& Dobbins, T. (2001). Teamworking: a new dynamic in the pursuit of management control. Human Resource Management Journal, 11(1), 3-23. https://doi.org/10.1111/j.1748-8583.2001.tb00029.x

Gerards, R., de Grip, A. \& Baudewijns, C. (2018). Do new ways of working increase work engagement?. Personnel Review, 47(2), 517-534. https://doi.org/10.1108/PR-02-2017-0050

Golden, T.D., Veiga J.F., \& Dino, R.N. (2008). The Impact of Professional Isolation on Teleworker job Performance and Turnover Intentions: Does Time Spent Teleworking, Interacting Face-to-Face, or Having Access to Communication-Enhancing Technology Matter?. Journal of Applied Psychology, 93(6), 1412-1421. https://doi.org/10.1037/a0012722

Gonsalves, L. (2020). From Face Time to Flex Time: The Role of Physical Space in Worker Temporal Flexibility. Administrative Science Quarterly, 65(4), 1058-1091. https://doi.org/10.1177/0001839220907891

Hafermalz, E., \& Riemer, K. (2020). Interpersonal connectivity work: Being there with and for geographically distant others. Organization Studies. https://doi.org/10.1177/0170840620973664

Halford, S. (2005). Hybrid workspace: re-spatialisations of work, organisation and management. New Technology, Work and Employment, 20(1), 19-33. https://doi.org/10.1111/j.1468-005X.2005.00141.x

Hancock, P. \& Spicer, A. (2011). Academic architecture and the constitution of the new model worker. Culture and Organization, 17 (2), 91-105. https://doi.org/10.1080/14759551.2011.544885

Harris, L. (2003). Home-based teleworking and the employment relationship. Managerial challenges and dillemas. Personnel Review, 32(4), 422-437. https://doi.org/10.1108/00483480310477515

Hirschman A. (1970). Exit, Voice, and Loyalty : Responses to Decline in Firms, Organizations, and States. Cambridge : Harvard University Press.

Hirst, A. (2011). Settlers, Vagrants and Mutual Indifference: Unintended Consequences of Hot-Desking. Journal of Organizational Change Management, 24(6), 767-788. https://doi.org/10.1108/09534811111175742

Hislop, D., \& Axtell, C. (2009). To Infinity and Beyond?: Workspace and the Multi-location Worker. New Technology, Work and Employment, 24 (1): 60-75. https://doi.org/10.1111/j.1468-005X.2008.00218.x 
Quote as : Ajzen, M., Taskin, L. (2021) The re-regulation of working communities in the contexte of flexwork : A spacing identity approach. Information and Organization, 31(3), https://doi.org/10.1016/j.infoandorg.2021.100364

Huws, U. (2014). Labor in the global digital economy : the cybertariat comes of age. New-York : Monthly Review Press.

Irving, G.L., Ayoko., O.B. \& Ashkanazy, N.M. (2019). Collaboration, Physical Proximity and Serendipitous Encounters: Avoiding collaboration in a collaborative building. Organization Studies, 41(8), 1123-1146. https://doi.org/10.1177/0170840619856913

Jaakson, K., \& Kallaste, E. (2010). Beyond flexibility: reallocation of responsibilities in the case of telework. New Technology, Work and Employment, 25(3), 196-209. https://doi.org/10.1111/j.1468005X.2010.00248.x.

Jones, B. (2012). Women Who Opt Out. New York: New York University Press.

Kelliher, C., \& Anderson, D. A. (2010). Doing more with less? Flexible working practices and the intensification of work. Human Relations, 63(1), 83-106. https://doi.org/10.1177/0018726709349199

Kingma, S. (2018). New ways of working (NWW): work space and cultural change in virtualizing organizations. Culture and Organization, 1-24. https://doi.org/10.1080/14759551.2018.1427747

McNall, L.A., Masuda, A.D., \& Nicklin, J.M. (2009). Flexible Work Arrangements, Job Satisfaction, and Turnover Intentions: The Mediating Role of Work-to-Family Enrichment. The Journal of Psychology, 144(1), 61-81. https://doi.org/10.1080/00223980903356073

Leonardi, P., Treem, J., \& Jackson, M. (2010). The Connectivity Paradox: Using Technology to Both Decrease and Increase Perceptions of Distance in Distributed Work Arrangements. Journal of Applied Communication Research, 38(1), 85-105. https://doi.org/10.1080/00909880903483599

Martin, B., \& MacDonnell, R. (2012). Is telework effective for organizations?: A meta- analysis of empirical research on perceptions of telework and organizational outcomes. Management Research Review, 37(7), 602-616. https://doi.org/10.1108/01409171211238820

McBride, J. \& Martínez Lucio, M. (2016). Disaggregating and reaggregating work: Workers, management and the struggle over creating coherency and purpose in a context of work degradation. Human Resource Management Journal, 26(4), 490- 504. https://doi.org/10.1111/1748-8583.12118.

Messenger, J.C. \& Gschwind, L. (2016). Three generations of Telework: New ICTs and the (R)evolution from Home Office to Virtual Office. New Technology, Work and Employment, 31:3, 195-208. https://doi.org/10.1111/ntwe.12073

Nelson, M.R., Rademacher, M.A. \& Paek, H. (2007). Downshifting consumer = upshifting citizen? An examination of a local freecycle community. Annals of the American Academy of Political and Social Sciences, 611, 141-156.

Ongaki, J. (2019). An examination of the relationship between flexible work arrangements, work-family conflict, organizational commitment, and job performance. Management, 23(2), 169-187. https://doi.org/10.2478/manment-2019-0025

Paillé, P., \& Mucchielli, A. (2016). L'analyse qualitative en sciences humaines et sociales. (3rd ed.). Paris: Armand Colin

Peters, P., Poutsma, E., Van Der Heijden, B., Bakker, A., \& De Bruijn, T. (2014). Enjoying new ways to work: an HRM-process approach to study flow. Human Resource Management, 53(2), 271-290. https://doi.org/10.1002/hrm.21588

Pierce, J., Martin, G.M. \& Murphy, J.T. (2011). Relational place-making: The networked politics of place. Transactions, 36, 54-70.

Pyöriä, P. (2011). Managing Telework: Risks, Fears and Rules. Management Research Review, 34(4), 386-399. https://doi.org/10.1108/01409171111117843

Richardson, J. (2010). Managing Flexworkers: Holding On and Letting Go. Journal of Management Development, 29(2), 137-147. https://doi.org/10.1108/02621711011019279

Richardson, J., \& McKenna, S. (2014). Reordering Spatial and Social Relations: A Case Study of Professional and Managerial Flexworkers. British Journal of Management, 25, 724-736. https://doi.org/10.1111/1467$\underline{8551.12017}$

Rooney, D., Paulsen, N., Callan, V.J., Brabant, M., Gallois, C., \& Jones, E. (2010). A New Role for Place Identity in Managing Organizational Change. Management Communication Quarterly, 24(1), 44- 73. https://doi.org/10.1177/0893318909351434

Sewell, G., \& Taskin, L. (2015). Out of sight, out of mind in a new world of work? Autonomy, control and spatiotemporal scaling in telework. Organization Studies, 36(11), 1507-1529. https://doi.org/10.1177/0170840615593587

Stang-Våland, M., \& Georg, S. (2018). Spacing identity: Unfolding social and spatial-material entanglements of identity performance. Scandinavian Journal of Management, 34 (2), 193-204. https://doi.org/10.1016/j.scaman.2018.04.002

Solís, M. (2017). Moderators of telework effects on the work-family conflict and on worker performance. European Journal of Management and Business Economics, 26(1), 2134. https://doi.org/10.1108/EJMBE-07-2017-002 
Quote as : Ajzen, M., Taskin, L. (2021) The re-regulation of working communities in the contexte of flexwork : A spacing identity approach. Information and Organization, 31(3), https://doi.org/10.1016/j.infoandorg.2021.100364

Taskin, L., \& Edwards, P.K. (2007). The possibilities and limits of telework in a bureaucratic environment: Lessons from the public sector. New Technology, Work and Employment, 22(3), 195-207. https://doi.org/10.1111/j.1468-005X.2007.00194.X

Taskin, L., \& Bridoux, F. (2010). Telework : a challenge to knowledge creation and transfer. International Journal of Human Resource Management, 21(3), 2503-2520. https://doi.org/10.1080/09585192.2010.516600

Taskin, L., Ajzen, M., Donis, C. (2017). New Ways of Working: From Smart to Shared Power. In V. Muhlbauer $\&$ W. Harry (Eds.), Redefining Management. Smart Power Perspectives (pp. 65-80). London: Springer

Taskin, L., Parmentier, M., \& Stinglhamber, F. (2019) The dark side of of ce designs: towards de-humanization. New Technology, Work and Employment, 34(3), 262-284. https://doi.org/10.1111/ntwe.12150

Taylor, S., \& Spicer, A. (2007). Time for space: A narrative review of research on organizational spaces. International Journal of Management Reviews, 9(4), 325-346. https://doi.org/10.1111/j.14682370.2007.00214.X

Thatcher, S.M.B., \& Zhu, X. (2006). Changing identities in a changing workplace: Identification, identity enactment, self-verification, and telecommuting. Academy of Management Review, 31(4), 1076-1088. https://doi.org/10.5465/amr.2006.22528174

Thorne, K. (2005). Designing virtual organizations? Themes and trends in political and organizational discourses. Journal of Management Development, 24(7), 580-607. https://doi.org/10.1108/02621710510608731

Tietze, S., \& Nadin, S. (2011). The Psychological Contract and the Transition from Office-Based to Tele-Based Work. Human Resource Management Journal, 21(3), 318-334. https://doi.org/10.1111/j.17488583.2010.00137.x

Tremblay, D.G., \& Thomsin, L. (2012). Telework and Mobile Working: Analysis of Its Benefits and Drawbacks. International Journal of Work Innovation 1(1), 100-113. https://doi.org/ 10.1504/IJWI.2012.047995

Van Maanen, J. (ed.) (1979), Qualitative methodology. Beverly Hills: Sage.

van der Lippe, T. \& Lippényi, Z. (2020). Co-workers working from home and individual and team performance. New Technology, Work and Employment, 35(1), 60-79. https://doi.org/10.1111/ntwe.12153

Vayre, E., \& Pignault, A. (2014). A Systemic Approach to Interpersonal Relationships and Activities among French Teleworkers. New Technology, Work and Employment, 29(2), 177-192. https://doi.org/10.1111/ntwe.12032

Vilhelmson, B., \& Thulin, E. (2016). Who and where are the flexible workers? Exploring the current diffusion of telework in Sweden. New Technology, Work and Employment, 31(1), 7796. https://doi.org/10.1111/ntwe.12060

Wajcman, J. (2015). Pressed for Time. The Acceleration of life in digital capitalism, The University of Chicago Press: Chicago, p. 227.

Ybema, S. (2010). Talk of change: Temporal contrasts and collective identities. Organization Studies, 31(4), 481-503. https://doi.org/10.1177/0170840610372205 